\title{
Project Value Assessment of Thermal Power Plant based on RNPV Probit Model Considering Real Option*
}

\author{
Takafumi Hirose, ${ }^{a}$ Hajime Miyauchi ${ }^{a, \dagger}$ and Tetsuya Misawa ${ }^{b}$ \\ ${ }^{a}$ Graduate School of Science and Technology, Kumamoto University \\ b Graduate School of Economics, Nagoya City University
}

\begin{abstract}
Deregulation of electric power utilities are processing in the world. As the uncertainties of the business environment are increasing, return for asset investment is also uncertain. Therefore, the electric utilities should evaluate the appropriate value of the capital investment. When only the execution of the project is observed, we have proposed a risk assessment method for generation investment by the probit model (RNPV probit model) which simplifies the evaluation method by the net present value based on utility indifference pricing. In this paper, RNPV probit model is applied to asset evaluation of thermal power plant considering the option to abandon, a kind of real option.
\end{abstract}

Keywords: NPV; expected utility theory; utility indifference pricing; risk; real option; project value assessment; thermal power plant

\footnotetext{
*Received: June 23, 2011; Accepted: January 5, 2012.

${ }^{\dagger}$ Corresponding author. Address: 2-39-1 Kurokami, Kumamoto 860-8555, Japan; Phone: +81-96-342-3612; E-mail: miyauchi@cs.kumamoto-u.ac.jp
} 


\title{
リアルオプションを考慮した RNPV プロビットモデルに基づく 火力発電事業価値評価
}

\author{
廣瀬 高史 ${ }^{\mathrm{a}}$, 宮内 肇 ${ }^{\mathrm{a}}$, 三澤 哲也 ${ }^{\mathrm{b}}$ \\ $\mathrm{a}$ 熊本大学大学院自然科学研究科 \\ $\mathrm{b}$ 名古屋市立大学大学院経済学研究科
}

\section{1 はじめに}

電力自由化に伴い, 電気事業には不確実性（=リスク）が増大している.そのため, 適切な 事業価值評価法が必要とされている。事業価值の評価法として NPV（純現在価值）法がよく知 られているが，リスクへの対応は割引率を定める際の経験則に依存していることが多い. 市場 で扱われている財ではリスク中立で測ることが適しているが，必ずしも市場と関連しないプロ ジェクトの価值を測る際には，そこに含まれるリスク（CF：Cash Flow（キャッシュフロー）， 割引率）を含めた価值評価法を定式化することが重要である。その 1 つの方法として，効用無 差別価格理論に基づく NPV 法（UNPV: Utility indifference Net Present Value 法）による事 業価值評価が挙げられる。これは現在, 宮原孝夫氏によって提唱されている「リスク鋭感的価值 尺度」を効用関数に基づいて作成する際の具体的手法に相当しており [6, 7], UNPV 法は NPV 法の自然な拡張となっていること, またリスク価值尺度による方法と密接に関係していること が検証されている。我々は既に，火力発電事業を対象に，このUNPV 法を用いて事業の実行可 否に関する評価を行い，事業者のリスクに対する態度が UNPV 法で正当に評価されることを 示している。その際，リアルオプションの一つである事業からの撤退オプションを考慮に入れ た場合についても，UNPV 法による事業価値評価の検討を行っている [3].

UNPV 法では，事業者のリスクに対する考え方が効用関数を通じて表現される。電気事業 は莫大な投資を伴うためにリスクを回避する傾向にある。そのためリスク回避型の効用関数を 採用すべきであるが，過去の投資家のプロジェクト投資行動データからの効用関数の推定法が 確立されておらず，どのような効用関数が適切か，また適切な効用関数を選択できたとしても そのパラメータをどのようにして推定するか，といつた困難な問題が存在する。そこで我々は, 効用関数を前面に出さずにリスクを評価する方法として，ランダムな NPV（RNPV: Random Net Present Value）を基に，UNPV 法の簡約化から導かれる「プロビット型 RNPV 中心モー メント回帰モデル」（以下，RNPVプロビットモデルと記す）に基づいて事業決定を行う方法 を提案した [2]. この手法は過去のプロジェクトの採否実績に着目し, UNPV 法を簡約化して 導かれるプロビット回帰モデルを推定し，それに基づいて新規プロジェクトの採否が決定され る方法であり, UNPV 法における効用関数の推定と比較してモデルの推定が容易であるという 点で有利であると言える. 現在は提案手法の有効性を火力発電事業への投資問題を題材に検討 
を進めている $[1]$. その結果, 事業者がUNPV 法 に従って事業の実行, 非実行を決定している と仮定するとき，RNPV の分布が正規分布に近い場合は 2 次の中心モーメントまでの RNPV プロビットモデルによる事業の採否の判断とUNPV 法による採否の判断はほぼ一致すること, また, RNPV の分布が正規分布から離れるとともに，2次の中心モーメントまでの RNPV プ ロビットモデルよりも，3次，4次の高次中心モーメントまでも考慮した RNPV プロビットモ デルによるプロジェクトの採否の判断の方が，UNPV 法による採否の判断と整合することを示 している [5]. しかしながら, UNPV 法の有効性を評価する際に行った撤退オプションなど, 事 業者のリスクヘッジを考慮した場合に対する本モデルの有効性に関する検証はいまだ行ってい ない.

そこで，本論文では，事業者のリスクヘッジの手段として撤退オプションを取ることができ るものとし，そのようなケースにおける RNPV プロビットモデルの妥当性を検証するととも に，我々のモデルのフレームワークではこうしたリスクヘッジの効果が，どのように表現，評 価されるかについて論考する。

本論文では火力発電事業を対象とし, 簡単のために, コストである燃料価格と売価である電力 価格のみが平均回帰モデルで変動するとした単純なモデルを考える. 回帰モデルの各パラメー 夕を変動させ，まず，撤退オプションを考慮せずにモンテカルロ・シミュレーションを行い，多 数の RNPV を作成し，それを基に RNPV プロビットモデルを作成する。次に，撤退オプショ ンを考慮して RNPV を求め, その值を先に求めた RNPV プロビットモデルに代入することで 事業の実行の可否を判断する。撤退オプションを考慮した多数の試行に対し，RNPVプロビッ トモデルによる実行可否判断とUNPV 法による判断がどの程度整合しているか，また，撤退 オプションを考慮する場合には RNPV プロビットモデルで得られる評価值，すなわち，事業の 実行確率が高くなり，事業が実行される可能性が高くなることや，事業者がリスク回避的にな るほどリアルオプション効果が大きくなることを示す．以上のことから，撤退オプションを考 慮した場合も, RNPVプロビットモデルは事業の実行可否を正当に評価することを示す。また, プロジェクトの実行確率より事業者のリスクに対する感度が実行確率の数值を指標として示さ れるとともに, リアルオプションの意思決定におけるリスクヘッジ効果も数量的に示し得る.

このように，本論文では，既に提案している RNPV プロビットモデルの適用を，リアルオ プションを含む事業へと拡張することで, リスクに対する事業者の態度が正しく評価されるこ とを示し，それにより RNPVプロビットモデルの有効性を明らかにすることを目的とする.

\section{2 モデル}

\section{1 基本モデル}

\subsection{1 従来の評価手法}

NPV（Net Present Value: 純現在価值）法は事業の価值を評価する最も一般的な手法である. NPV 法はDCF（Discounted Cash Flow：割引キャッシュフロー）法とも呼ばれ，将来得られ 
るであろう CF（Cash Flow：キャッシュフロー）を現在の価值に換算することで投資の実行可 否を判断するものである。

現時点（第 0 年度末）に投資額 $I$ を一括投資することで，第 1 年度から第 $N$ 年度まで毎年， 第 $n$ 年度にはキャッシュフロー $C F_{n}$ が発生する事業を考える. $C F$ 列 $\left\{C F_{n}: n=1,2, \cdots, N\right\}$ を用いると，この事業の $P V$ (Present Value: 現在価值) は，

$$
P V=\sum_{n=1}^{N} \frac{C F_{n}}{(1+r)^{n}}
$$

で与えられる。ここで, $r$ は割引率である。そして, この事業の純現在価値 $N P V$ は, 現在価値 $P V$ から投資額 $I$ を引くことで求められる。 すなわち,

$$
N P V=P V-I
$$

NPV 法における投資の決定判断は，式 (3) で表せる.

$$
N P V \begin{cases}>0 & \text { (投資実行 }) \\ =0 & \text { (任意) } \\ <0 & \text { (投資不実行 })\end{cases}
$$

\subsection{2 期待効用理論による評価手法}

式 (1), (2) における将来得られる $\mathrm{CF}$ 列が確率変数 $\left\{X_{n}: n=1,2, \cdots, N\right\}$ で与えられた場 合, 現在価値 $P V$ と純現在価值 $N P V$ は,

$$
\begin{aligned}
& P V(X)=\sum_{n=1}^{N} \frac{E\left[X_{n}\right]}{(1+r)^{n}}=E\left[\sum_{n=1}^{N} \frac{X_{n}}{(1+r)^{n}}\right] \\
& N P V(X)=P V(X)-I
\end{aligned}
$$

で表現される. CF 列は確率変数であり, ランダムな現在価值 $R P V$ (Random Present Value）は,

$$
R P V(X)=\sum_{n=1}^{N} \frac{X_{n}}{(1+r)^{n}}
$$

と定義される。ここで, $E[R P V(X)]=P V$ である.

$R P V(X)$ の効用無差別価格を考え, それを $X$ の効用無差別現在価值 (Utility indifference Present Value) と呼び, $U P V(X)$ で示す. $U P V(X)$ は

$$
E\left[u\left(-v_{0}+R P V(X)\right)\right]=0
$$

を満たす $v_{0}$ の值である $[6]$. また，一試行毎の純現在価值 $R N P V$ は投資額 $I$ が一定ならば，式 (8)で与えられる.

$$
R N P V(X)=R P V(X)-I
$$


また， $X$ の効用無差別純現在価值 (Utility indifference Net Present Value) $U N P V(X)$ は

$$
E[u(-v-I+R P V(X))]=0
$$

を満たす $v$ の值である。式 $(7),(8)$ を比較すると, $v_{0}=v+I$ と導け,

$$
U N P V(X)=-I+U P V(X)
$$

が成立することがわかる。このとき，

$$
v>0 \text { ならば投資を実行， } v<0 \text { ならば投資非実行 }
$$

とする。これがUNPV 法である。なおこの場合の割引率 $r$ としては，投資家の効用関数に適合 したものを用いればよい $[4]$. 特に効用関数が $u(x)=x$ であれば,

$$
U N P V(X)=E[R N P V]=N P V(X)
$$

が導かれ，UNPV は従来の NPV に帰着されることに注意する。すなわち UNPV 法はNPV 法 の自然な拡張になっている。

\subsubsection{UNPV 法を簡約化したプロビットモデル}

本節では，提案しているプロビットモデルについて説明する。リスクを考慮する事業価值評 価手法である期待効用理論に基づく UNPV 法には，既に説明したように効用関数が使われて いる.しかし，例えリスク回避型の事業であるとしても，どのようなリスク回避型の効用関数 が適切なのか，また，適切な効用関数が定まったとしても，そのパラメータの同定が困難であ る。そこで，プロジェクトの採否だけに着目するならば，UNPV 法で得られた結果をプロビッ トモデルに帰着させることができ，効用関数を前面に出さずに事業価值評価が可能となる。な お, 提案手法においては, 結果的に事業価值評価の対象は事業そのものの価值の大小や取引価 格ではなく，プロジェクトの採否となる。

事業者の考えている効用関数 $u(x)$ が分からないと仮定する. $Y=-v-I+R P V(X)$ とお くと, 式 (9)は, 式 (12)のように書ける.

$$
E[u(Y)]=0
$$

式 (12)の左辺を例えば 2 次までのモーメントで近似展開すると,

$$
\begin{aligned}
E[u(Y)] & \approx u(E[Y])-u^{\prime}(E[Y]) E[(Y-E[Y])]+\frac{1}{2} u^{\prime \prime}(E[Y]) E\left[(Y-E[Y])^{2}\right] \\
& =u(E[Y])+\frac{1}{2} u^{\prime \prime}(E[Y]) E\left[(Y-E[Y])^{2}\right]
\end{aligned}
$$

ここで, $-I+R P V(X)=R N P V(X)=Z$ とおき, $E\left[(Z-E[Z])^{2}\right]=V(Z)$ と定義すると，

$$
u(E[Y])+\frac{1}{2} u^{\prime \prime}(E[Y]) E\left[(Y-E[Y])^{2}\right]=u(-v+E[Z])+\frac{1}{2} u^{\prime \prime}(-v+E[Z]) V(Z)
$$


式 (12), (13)より, 式 (14) は,

$$
u(-v+E[Z])+\frac{1}{2} u^{\prime \prime}(-v+E[Z]) V(Z) \approx 0
$$

となる. 式 $(15)$ の左辺が，適当な点 $\left(v_{0}, E[Z]_{0}, V(Z)_{0}\right)$ で, $v, E[Z], V(Z)$ に関して $C^{1}$ 級関数 とすると，陰関数定理により，その近傍で次の $C^{1}$ 級関数 $g$ を得る.

$$
v=g(E[Z], V(Z))
$$

さらに簡単のために, 関数 $g$ を $E[Z], V(Z)$ の線形関数で近似する. ただし, 式 $(12)$ と $u(0)=0$ より, $Z=0$ のとき $v=0$ であることを考慮すると，近似式として

$$
v \approx \alpha_{1} E[Z]+\alpha_{2} V(Z)
$$

を得るが，式 (17) を確定するには，右辺の各説明変数の回帰係数を求めなければならない。そ れには，過去のプロジェクト $i$ における UNPV の值 $v_{i}$ と $R N P V=Z$ の平均, 分散のデータ 值 $\left(v_{i}, E[Z]_{i}, V(Z)_{i}\right)(i=1, \ldots, n)$ から推定する回帰モデル

$$
v_{i}=\beta_{1}+\beta_{2} E[Z]+\beta_{3} V(Z)+\varepsilon_{i}
$$

を考える必要がある。ここで， $\varepsilon_{i}$ は標準正規分布に従う平均 0 の誤差項で, 式 $(17)$ のように近 似した際の誤差も含まれている.

ところで，事業者がUNPV 法にしたがってプロジェクトの採否を決定しているとしても，実 際に我々が入手できる情報は，UNPVの值 $v_{i}$ そのものではなく，プロジェクトの採否の結果 だけである。このことから，ここで二值関数 $v^{*}$ を設定し， $v>0$ ならばプロジェクトを採択し て $v^{*}=1$ とし, 逆にもし $v<0$ ならば否として $v^{*}=0$ とする. 過去のプロジェクトに関し て, この二值関数 $v^{*}$ と $R N P V=Z$ の平均, 分散からなるデータの組合せ $\left(v_{i}^{*}, E[Z]_{i}, V(Z)_{i}\right)$ $(i=1, \ldots, n)$ を作成する。 このデータから, 式 $(19)$ の尤度関数が得られる.

$$
\begin{aligned}
L\left(\beta_{1}, \beta_{2}, \beta_{3}\right)= & \prod_{v_{i}^{*}=1} F\left(\beta_{1}+\beta_{2} E[Z]_{i}+\beta_{3} V(Z)_{i}\right) \\
& \times \prod_{v_{i}^{*}=0}\left\{1-F\left(\beta_{1}+\beta_{2} E[Z]_{i}+\beta_{3} V(Z)_{i}\right)\right\}
\end{aligned}
$$

ここで $F$ は標準正規分布の累積分布関数

$$
F(x)=\int_{-\infty}^{x} \frac{1}{\sqrt{2 \pi}} e^{-\frac{1}{2} t^{2}} d t
$$

である。

式 (19) より対数尤度関数は式 (21) で表される.

$$
\begin{aligned}
\log L\left(\beta_{1}, \beta_{2}, \beta_{3}\right)=\sum & {\left[v_{i}^{*} \log F\left(\beta_{1}+\beta_{2} E[Z]_{i}+\beta_{3} V(Z)_{i}\right)\right.} \\
& \left.+\left(1-v_{i}^{*}\right) \log \left\{1-F\left(\beta_{1}+\beta_{2} E[Z]_{i}+\beta_{3} V(Z)_{i}\right)\right\}\right]
\end{aligned}
$$


これを最大化する式 (18)の係数を最尤法で求める。すなわち, 式 (18) をプロビットモデルと して推定する。なお，この問題では $v$ の符号（正負）だけを問題としている（プロジェクトの 採否）ので，誤差項 $\varepsilon_{i}$ の分散を 1 としても一般性は失わないことに注意する。

以上のデー夕を元に得られた回帰係数を, $\hat{\beta}_{0}, \hat{\beta}_{1}, \hat{\beta}_{2}$ とすれば,

$$
\hat{v}=\hat{\beta}_{0}+\hat{\beta}_{1} E[Z]+\hat{\beta}_{2} V(Z)
$$

が簡約化による最終的な結果である $[2]$.これに評価したい $R N P V=Z$ の期待值と分散を代入 し， $\hat{v}>0$ ならばプロジェクトを実行と判断すればよい.こうして UNPVの簡約化から得られ たプロビットモデルを RNPV プロビットモデルと呼ぶ。なお，ここでは 2 次のモデルについて 紹介したが, さらに高次のモデルについても同様に導ける [2].

\section{2 想定モデル}

本論文では，LNG を燃料とする新設火力発電施設の事業価值評価を行う。簡単のため，以下 の仮定をおく.

・建設のリードタイムは考慮しない

・事業年数を 22 年間とする

・想定する不確実さは電力価格と燃料価格のみとする

・電力価格と燃料価格は平均回帰モデルで表され，1 日単位で変化する

・電力取引は前日スポット市場のみで行われる

・ 検討している発電機が参入しても電力市場価格は変化しない

- 発電機は 8 時〜 22 時までの 14 時間定格で出力し, 発電した電力はすべて売電される

・発電機の起動停止コストは考慮しない

\subsection{1 年間収益の評価モデル}

本論文では電力価格, 燃料価格を不確実なものとし, 確率変数で表す。そのためキャッシュフ ロー CF も確率過程である. 税なども考慮しないため, 以下 $\mathrm{CF}$ と収益は等しいものとして取 り扱う。電力スポット市場では 30 分もしくは 1 時間といつた定められた時間単位で取引が行わ れる，取引される発電量 (エネルギー) の単位は $\mathrm{kWh}$ であるため, スポット市場の取引時間単 位を 1 時間とすると収益計算が簡単であるので, 本論文ではスポット市場での取引時間単位を 1 時間とする。これより, 発電事業の年間 $(24 \times 365=8760$ 時点 $)$ の収益 profit は,

$$
(\text { profit })=\sum_{j=1}^{8760}\left(E P_{j} \times P O_{j}\right)-\sum_{j=1}^{8760}\left(H^{\prime} \times C P_{j} \times P O_{j}\right)-O M C \times P O_{\max }
$$


$j:$ 時間を表す添え字 [hour]

$E P:$ 電力価格 $[\mathrm{yen} / \mathrm{kWh}]$

$P O:$ 発電量 $[\mathrm{kWh}]$

$H^{\prime}$ : 発電効率費 $[($ yen $\cdot$ barrel $) /(\$ \cdot \mathrm{kWh})]$

$C P:$ LNG 価格 $[\$ / \mathrm{mmBTU}]$

$O M C$ : 運転維持費 (Operating and Maintenance Cost) [yen/kWh]

$P O_{\text {max }}$ : 定格出力 $[\mathrm{kWh}]$

で表される，右辺第二項の $\left(H^{\prime} \times C P\right)$ は燃料価格に相当する。ここで各時点の発電電力を定格 出力と仮定しているので,

$$
\text { (profit) }=\left(\sum_{j=1}^{8760}\left(E P_{j}-H^{\prime} \times C P_{j}\right)-O M C\right) \times P O_{\max }
$$

と表せ，収益は単純に $1 \mathrm{kWh}$ あたり収益に定格出力をかけた式で表すことができる，発電機は 8 時〜 22 時までの 14 時間運転で，1 日の電力価格，市場価格は変化しないとしているので，年 間収益は, 式 $(25)$ で表される。

$$
(\text { profit })=\sum_{i=1}^{365}\left(14 \times\left(E P_{i}-H^{\prime} \times C P_{i}\right)\right)-O M C
$$

ここで， $i$ は年間のある日を表す。電力価格 $E P$ や LNG 価格 $C P$ は平均回帰モデルで表現さ れ, 式 (25) で得られる (profit) が $\mathrm{CF}$ 列 $\left\{X_{n}: n=1,2, \ldots, N\right\}$ の確率変数 $X$ の值である.

本論文では，式 (24)で示したように，年間の収益は， $1 \mathrm{kWh}$ あたり収益に定格出力をかけて 表すことができ，逆に言えば，事業価值を $\mathrm{kWh}$ 当たりで評価することになる，さらに，検討す る発電機の参入が電力市場価格に影響しないものとし, 特に発電機の設備容量 $(\mathrm{kW})$ を想定し ていない. しかし，これらの点については，電力市場で取引される電力が検討する発電設備に 比べ十分大きいと想定すれば問題ではなく，また，市場取引そのものをモデル化すれば，本手 法を用いて発電設備の設備容量も考慮した事業価值評価が可能である。したがって, 本論文に おいて，これらの仮定をおき，事業価值を $\mathrm{kWh}$ 当たりで評価することは妥当であり，本手法の 適用を制限しているものではない.

\subsection{2 平均回帰モデル}

本論文では簡単のために電力市場価格の週間，季節ごとなどの周期的変動を考慮しないこと とし, 単純な平均回帰モデルで電力市場価格の大局的変動のみを表現する. 平均回帰モデルは, 市場価格 $S$ に対して式 (26) で表わされる。

$$
d S=\alpha(\mu-\ln S) S d t+\sigma S d z
$$

ここで， $\alpha$ は平均回帰率， $\mu$ は長期価格水準 $\bar{S}$ の対数值， $\sigma$ はボラティリティである. 
式 (26) は, 市場価格の自然対数 $x=\ln S$ をとれば, 式 (27) のように書き換えることができる.

$$
d x=\left[\alpha(\mu-x)-\frac{1}{2} \sigma^{2}\right] d t+\sigma d z
$$

この式を時間単位 $t$ で離散化すると,

$$
\Delta x_{t}=\left[\alpha\left(\mu-x_{t}\right)-\frac{1}{2} \sigma^{2}\right] \Delta t+\sigma \sqrt{\Delta t} \varepsilon_{i}
$$

となる。ただし，この離散化においては，ドリフト項が変数 $x$ に依存するため，極めて 0 に近 い時間刻み $\Delta t$ を選ぶ必要がある。現実的には，平均回帰率に比べて十分短い時間刻み $\Delta t$ を選 定する。よって式 $(25)$ における電力価格 $E P_{i}$, 燃料価格 $C P_{i}$ は,

$$
\begin{aligned}
& E P_{i}=E P_{i-1} \times \exp \left\{\left[\alpha_{1}\left(\mu_{1}-x_{1, i-1}\right)-\sigma_{1}^{2} / 2\right] \Delta i+\sigma_{1} \sqrt{\Delta i} \varepsilon_{1, i}\right\} \\
& C P_{i}=C P_{i-1} \times \exp \left\{\left[\alpha_{2}\left(\mu_{2}-x_{2, i-1}\right)-\sigma_{2}^{2} / 2\right] \Delta i+\sigma_{2} \sqrt{\Delta i} \varepsilon_{2, i}\right\}
\end{aligned}
$$

で表現されるものとする.

\section{3 シミュレーション方法}

\subsection{1 パラメータ}

表 1 に, 数值計算に用いたパラメータを示す。長期価格水準 $\bar{S}$, 平均回帰率 $\alpha$, ボラティリティ ののパラメータについてはそれぞれ, 表 1 に示す範囲で多数変化させ, 計 255 ケースのシミュ レーションを行った。 また，表 1 に示す電力価格の長期価格水準 $\bar{S}_{E}$ は初期值であり，毎年一 定確率で上昇 (up) あるいは下降 (down) するものとした。本論文では, up 確率を $p$, down 確 率を $q(=1-p)$ とし $, p, q$ ともに 0.5 とした。この $p, q$ に基づいて, 電力価格の長期価格水準 $\bar{S}_{E}$ は，毎年，前年の $0.5 \%$ だ増加または減少するものとする.

各ケースについて 10,000 回試行を行い，10,000 個の RNPVを計算する.

\subsection{2 撤退オプション}

電力価格の長期価格水準が下降した場合，年間の平均電力価格が下がるため収益が低下する. 事業の収益が負となったときに資本回収をあきらめ, 事業を中止することでこれ以上の損失を 出さないことを目的に, 撤退オプションを考慮する. 本論文では以下のように撤退オプション を設定した。撤退オプションの導入により，リスク回避的である事業者の投資意欲の変化は実 行確率の変化として数量的に示すことができるものと考えられる，そのため，本論文では撤退 オプションの有無による差異を比較することを目的としており，下記の意思決定におけるup 回 数と down 回数の差は, 例示的に 5 回と設定したものに過ぎない. 
表 1: 数値シミュレーションのパラメータ

\begin{tabular}{l|c|c}
\hline & 電力価格 $E P$ & LNG 価格 $C P$ \\
\hline $\bar{S}:$ 長期価格水準 & $9.1-9.9[\mathrm{yen} / \mathrm{kWh}]$ & $5.7-6.5[\$ / \mathrm{mmBTU}]$ \\
$\alpha:$ 平均回帰率 & $70-150$ & $5-30$ \\
$\sigma:$ ボラティリティ & $3.0-3.6$ & $0.5-2.0$ \\
\hline$\Delta t:$ 離散時間 & $1 / 365[1 / \mathrm{day}]$ \\
$H:$ 発電効率 & $7.9 \times 10^{-3}[\$ / \mathrm{mmBTU}]$ \\
$r a t e:$ 為替レート & $100[\mathrm{yen} / \$]$ \\
$H^{\prime}$; 発電効率費 & $0.79[\mathrm{yen} \cdot \mathrm{mmBTU}]$ \\
$O M C:$ 運転維持費 & $9,636[$ yen $/(\mathrm{kW} \cdot \mathrm{year})]$ \\
$I:$ 建設コスト & $2.0 \times 10^{5}[\mathrm{yen} / \mathrm{kW}]$ \\
$n:$ 施設の廃棄年数 & $22[\mathrm{year}]$ \\
$r:$ 割引率 & 0.03 \\
\hline
\end{tabular}

・事業開始から 5 年毎に事業を撤退するかどうかの意思決定を行う

- 意思決定の年に, 電力価格の長期水準が上がった回数よりも下がった回数が 5 回以上多け れば（down 回数 - up 回数 $\geq 5$ 回であれば），事業から撤退する

\section{3 結果と考察}

本節では，以下の順に計算し，検討を行う。すなわち，撤退オプションを考慮しない新規プ ロジェクト (火力発電事業) について RNPVを計算し，2 次中心モーメントまでの RNPV プ ロビットモデルを推定する。そして，その RNPVプロビットモデルを用いて，撤退オプション を考慮しない場合の事業の採否結果を求める。次に，撤退オプションを考慮した場合について RNPV を計算し，そのデータに対して，撤退オプションを考慮しない場合の RNPVから求め た RNPV プロビットモデルに基づいて，事業の採否結果を求める。撤退オプションを考慮しな い場合と考慮する場合について事業の採否結果について比較する。次いで，撤退オプションを 考慮しない場合と考慮する場合について，実行確率やリスク感度を求め比較する.

\subsection{UNPV の比較}

本節では 2.3.1節で述べたように, 火力発電事業に関して, 市場価格の長期価格水準 $\bar{S}$, 平均 回帰率 $\alpha$, ボラティリティ $\sigma$ のパラメータを変化させた 255 ケースについて, 撤退オプションを 考慮した場合と考慮しない場合の双方を，2.1.2 節で述べた UNPV 法により評価し，比較検討 
表 2: UNPV の平均值及び UNPV によるプロジェクトを採とした数

\begin{tabular}{c|cc}
\hline 撤退オプション & 考慮しない場合 & 考慮する場合 \\
\hline $\mathrm{UNPV}$ 平均值 & $-15,283.62$ & $-8,076.13$ \\
プロジェクト採の数 & 50 & 92 \\
\hline
\end{tabular}

表 3: プロビットモデルによる $\hat{v}$ の平均值及び $\hat{v}$ 值によるプロジェクトを採とした数

\begin{tabular}{c|cc}
\hline 撤退オプション & 考慮しない場合 & 考慮する場合 \\
\hline$\hat{v}$ 值平均 & -10.95 & -7.35 \\
プロジェクト採の数 & 49 & 72 \\
\hline
\end{tabular}

する.なおここでは, 事業者は, リスク回避的な指数型効用関数 $u(x)=1-\exp (-\beta x)(\beta>0)$ に従うものとしてUNPVを求めている.

撤退オプションを考慮しない場合と考慮した場合の，UNPVの平均値とUNPVの正負に基 づくプロジェクトを採とした数を，表 2 に示す。撤退オプションを考慮した場合，考慮しない 場合よりもプロジェクトを採とした数が増え，また，UNPVの平均值も大きい，撤退オプショ ンを考慮した場合, UNPVの值が大きくなったケースは 255 ケース中 245 ケースである. 以上 のことから，撤退オプションを考慮すると，事業の実行可能性が高く評価されていることがわ かる.

\section{2 プロビットモデルによる事業採否の比較}

次に，2.1.3節で述べたプロビットモデルによる事業の採否について比較する。撤退オプショ ンを考慮しない場合の RNPV からプロビットモデルを求めると，式 (31) が得られる. 各回帰 係数の下に括弧書きされた值は $t$ 值を表す.

$$
\begin{gathered}
\hat{v}=-8.394+6.945 \times 10^{-4} E[Z]-1.068 \times 10^{-7} V(Z) \\
(-3.143) \quad(3.196)
\end{gathered}
$$

なお，この回帰式の対数尤度は -7.331 であった。

このプロビットモデルに，撤退オプションを考慮しない場合，考慮した場合の両方について， $Z=R N P V$ を代入し左辺の值 $\hat{v}$ 求める。付録 $\mathrm{A}$ の表 5-13に，撤退オプションを考慮した 場合としない場合の $\hat{v}$ 值の差，すなわち（撤退オプションを考慮した場合の $\hat{v}$ 值）-（撤退才 プションを考慮しない場合の $\hat{v}$ 值）を示す。 255 ケース中 254 ケースで, $\hat{v}$ 值が撤退オプション を考慮した場合の方が大きい. また，式 (31) のプロビットモデルを用いて事業の採否を求めた 結果を表 3 に示す. 
廣瀬 高史・宮内 肇・三澤 哲也

表 4: プロジェクト実行確率

\begin{tabular}{c|ccccccccccc}
\hline 撤退オプション & 0 & 0.1 & 0.2 & 0.3 & 0.4 & 0.5 & 0.6 & 0.7 & 0.8 & 0.9 & 1.0 \\
\hline 考慮しない場合 & 198 & 3 & 1 & 0 & 1 & 2 & 0 & 0 & 3 & 0 & 46 \\
考慮する場合 & 164 & 6 & 2 & 0 & 8 & 3 & 0 & 0 & 7 & 2 & 62 \\
\hline
\end{tabular}

撤退オプションを考慮した場合の方が考慮しない場合よりプロビットモデルの $\hat{v}$ 值が大きい. しかし, 表 2 に示す UNPV 法による事業採否を求めた結果と比較すると, 撤退オプションを考 慮した場合に，プロジェクトを採とする数がかなり減つていることに気付く。これは，撤退才 プションを考慮した場合でも, 式 (31) の撤退オプションを考慮しない結果に基づくプロビット モデル，すなわち，過去のプロジェクトの実行判断において撤退オプションを考慮していない モデルに基づくためと考えられる。

\section{3 実行確率}

前節のプロビットモデル值 $\hat{v}$ は符号のみにプロジェクトの採否という意味があり，值そのも のには特に意味はない. しかし，その $\hat{v}$ の值を用いることでプロジェクトの実行確率を計算す ることができる。すなわち，あるプロジェクトに関する $R N P V=Z$ の平均 $E[Z]$, 分散 $V[Z]$ を求め, 推定したプロビットモデルにそれらの值を代入して求めた $\hat{v}$ 值を, 標準正規分布の累 積分布関数に代入すれば，プロジェクトの実行確率を求めることができる。すなわち，

$$
\hat{P}=F(\hat{v})
$$

を計算することでプロジェクトの実行確率 $\hat{P}$ が求められる。ここで，Fは標準正規分布の累積 分布関数である。プロジェクトが採，すなわち $\hat{v}>0$ であるとき $\hat{P}>0.5$ となり，プロジェク トが否，すなわち $\hat{v}<0$ であるとき $\hat{P}<0.5$ となる. 表 4 に実行確率を計算した結果を示す. これより，撤退オプションを考慮した場合の方が実行確率は全体的に大きいことがわかる.

\section{4 リスク感度分析}

前節で計算した $\hat{P}$ の值と推定されたプロビットモデルを用いることで, リスク感度分析がで きる. 推定したプロビットモデル $\hat{v}=\hat{\beta}_{0}+\hat{\beta}_{1} E[Z]+\hat{\beta}_{2} V[Z]$ で, 平均 $E[Z]$ をある值に固定し, 分散 $V[Z]$ の二乗根, すなわち, 標準偏差 $\sigma$ （リスクに相当する）を 0 から少しずつ増やし, そ の時々の $\hat{v}$ 值の值から, プロジェクトの実行確率 $\hat{P}$ を計算することで, リスクの増加に対する $\hat{P}$ の変化（プロジェクト実行確率曲線）を見ることができる.

式 (31) において, RNPVの平均 $E[Z]$ を, 平均值（撤退オプションを考慮しない場合は 17,950.98, 撤退オプションを考慮する場合は 19,364.22) で固定し, 標準偏差 $\sigma$ を 15,000 と 変化させることで，プロジェクト実行確率曲線を求める。結果を図 1 に示す。図中, 一点鎖線 


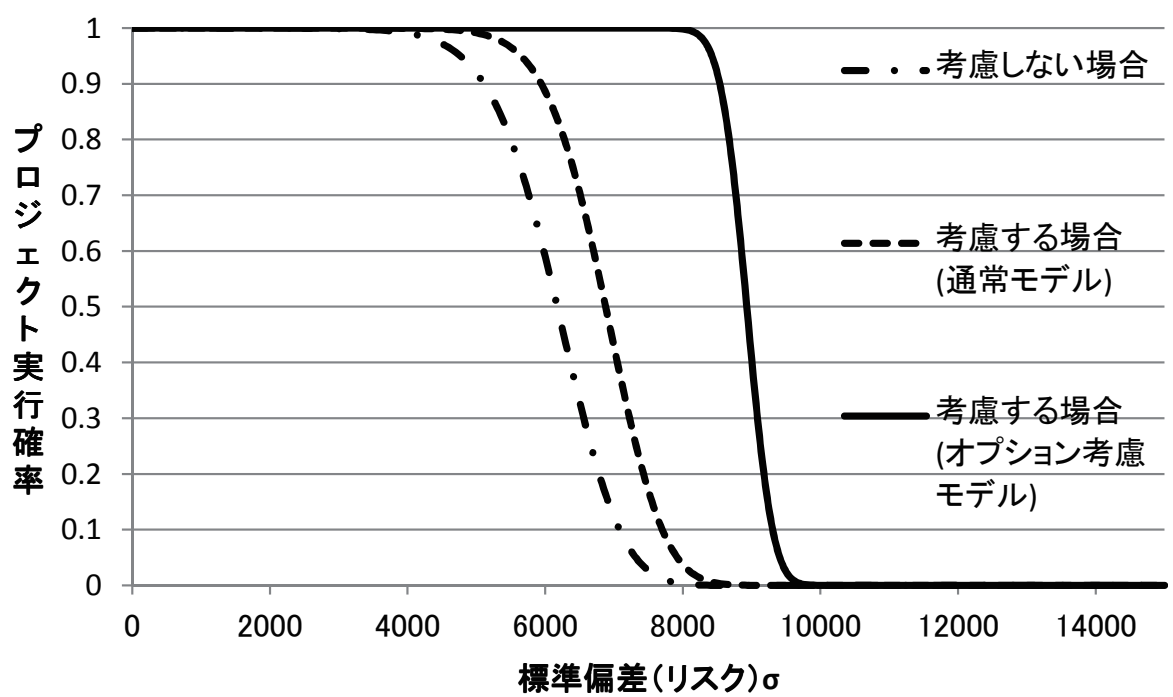

図 1:プロジェクト実行確率曲線

が撤退オプションを考慮しない場合，点線が撤退オプションを考慮する場合である。これより， 撤退オプションを考慮する場合の方が，リスク（標準偏差）が増えた場合でも実行確率が高く， プロジェクトが採用されやすいことがわかる.

次に，撤退オプションを考慮した場合の RNPVから推定したプロビットモデルを式 (33)に 示す．以下，両者を区別するために，式 (31) のモデルを通常モデル，式 (33)のモデルをオプ ション考慮モデルと呼ぶ.

$$
\begin{gathered}
\hat{v}=-1.805+8.630 \times 10^{-4} E[Z]-1.870 \times 10^{-7} V(Z) \\
(-1.786) \quad(3.642)
\end{gathered}
$$

なお, 各回帰係数の下の括弧書きの数值は $t$ 值であり, 対数尤度は -14.08 である. オプション を考慮したデータに基づく推計モデルを用いることで, 事業者にとつてのオプションの価值評 価がより精密になるものと考えられる。そこで，式 (33) を用いて撤退オプションを考慮した場 合の実行確率曲線を求めた結果が, 図 1 の実線である. 図 1 の実線は, 他の 2 つの場合と比較し て, リスクに対して一番高い実行確率を示していることから, 実行確率の観点からもオプショ ンのリスクヘッジ効果が顕著に現れていると言える.

\section{4 まとめ}

本論文では，すでに提案している RNPV プロビットモデルを，リアルオプションである撤退 オプションを含む事業に拡張して適用し，比較検討を行った。その結果，プロビットモデルで 
評価した場合でも，リアルオプションを考慮すると，考慮しない場合に比べ，UNPV 法による 事業評価と同様に事業を採とする数が多く, 本論文で用いた RNPV プロビットモデルは撤退オ プションを考慮した場合にも適切な評価を行っていることを示した。しかし，UNPV法による 結果と比較した場合，事業を採とする数が減るが，これは，撤退オプションを考慮しない場合 のデータを基に作成した RNPV プロビットモデルを用いて評価しているためと考えられる。ま た，プロビットモデルにより実行確率やリスク感度分析も行った。撤退オプションを考慮した 場合の方が, プロジェクトの実行確率が高くなり, また, リスクが増えてもそのプロジェクト が実行される可能性が高くなることが示され，プロビットモデルは撤退オプションの効能を正 しく表している。さらに，プロジェクトの実行確率はオプション導入による投資家の投資意欲 の変化を明示的・数量的に表していると言える.

なお本論文はまだ基礎的な検討に過ぎず，本方法に関しては以下の課題が残されている：

・過去にリアルオプションでの実行判断の実績があるプロビットモデルを用いた RNPV プ ロビットモデルの検証

・さまざまなリスク（例えば市場リスク等）ごとの UNPVおよび RNPV 法への影響の検証

・ RNPVの高次モーメント項を考慮した場合のリアルオプション効果の検証

- 式 (17) の近似を行う際の非線形項の考慮と式 (18) における非線形回州推定の検討

・プロジェクト採否そのものをオプションとみなしての事業価值評価の検証

これらの課題については今後順次検討を進めていく予定である.

\section{A 付録}

3.2 節の式 (31) を用いて，(撤退オプションを考慮した場合の $\hat{v}$ 值）-（撤退オプションを考 慮しない場合の $\hat{v}$ 值）を計算した結果を，表 5-13 に示す。

\section{謝辞}

本研究の遂行に当たり，名古屋市立大学宮原孝夫名誉教授には有益なご助言を多数頂き，深 く感謝致します。本論文に対し査読者の方々から様々な有益なコメントを頂戴したことを心よ り感謝致します。なお本論文は, 日本学術振興会科学研究費補助金 (基盤研究 (C) 20560273, な らびに基盤研究 (C) 21540140）の助成を受けて行った研究成果の一部をまとめたものである. 
表 5: $\bar{S}_{E}$ と $\bar{S}_{F}$ を変えた場合の $\hat{v}$ 值の差 $\left(\alpha_{E}=110, \alpha_{F}=20, \sigma_{E}=3.3, \sigma_{F}=1.0\right)$

\begin{tabular}{c|ccccc}
\hline $\bar{S}_{F}$ & $\bar{S}_{E}=9.1$ & $\bar{S}_{E}=9.2$ & $\bar{S}_{E}=9.3$ & $\bar{S}_{E}=9.4$ & $\bar{S}_{E}=9.5$ \\
\hline 5.7 & 3.09 & 3.10 & 3.21 & 3.51 & 3.33 \\
5.8 & 3.25 & 3.27 & 3.30 & 3.46 & 3.51 \\
5.9 & 3.71 & 3.63 & 3.68 & 3.47 & 3.99 \\
6.0 & 3.32 & 3.46 & 3.70 & 3.51 & 3.58 \\
6.1 & 3.43 & 3.58 & 3.54 & 3.48 & 3.68 \\
6.2 & 3.44 & 3.51 & 3.77 & 3.55 & 3.70 \\
6.3 & 3.57 & 3.78 & 3.94 & 4.32 & 3.84 \\
6.4 & 3.59 & 3.40 & 3.31 & 3.34 & 3.73 \\
6.5 & -5.12 & 3.39 & 3.77 & 3.73 & 16.35 \\
\hline
\end{tabular}

表 6: $\bar{S}_{E}$ と $\bar{S}_{F}$ を変えた場合の $\hat{v}$ 值の差 $\left(\alpha_{E}=110, \alpha_{F}=20, \sigma_{E}=3.3, \sigma_{F}=1.0\right)$

\begin{tabular}{c|cccc}
\hline $\bar{S}_{F}$ & $\bar{S}_{E}=9.6$ & $\bar{S}_{E}=9.7$ & $\bar{S}_{E}=9.8$ & $\bar{S}_{E}=9.9$ \\
\hline 5.7 & 3.35 & 3.46 & 3.78 & 3.73 \\
5.8 & 3.52 & 3.56 & 3.72 & 3.64 \\
5.9 & 3.90 & 3.94 & 3.73 & 4.05 \\
6.0 & 3.73 & 3.98 & 3.77 & 4.28 \\
6.1 & 3.85 & 3.80 & 3.74 & 3.54 \\
6.2 & 3.78 & 4.06 & 3.84 & 4.04 \\
6.3 & 4.08 & 4.24 & 4.63 & 4.41 \\
6.4 & 3.53 & 3.44 & 3.46 & 4.03 \\
6.5 & 3.47 & 3.86 & 3.83 & 3.87 \\
\hline
\end{tabular}

表 7: $\alpha_{E}$ と $\bar{S}_{F}$ を変えた場合の $\hat{v}$ 值の差 $\left(\bar{S}_{E}=9.5, \alpha_{F}=20, \sigma_{E}=3.3, \sigma_{F}=1.0\right)$

\begin{tabular}{c|cccc}
\hline $\bar{S}_{F}$ & $\alpha_{E}=70$ & $\alpha_{E}=80$ & $\alpha_{E}=90$ & $\alpha_{E}=100$ \\
\hline 5.7 & 3.22 & 3.06 & 3.51 & 3.53 \\
5.8 & 3.39 & 3.10 & 3.49 & 3.08 \\
5.9 & 3.95 & 3.51 & 3.15 & 3.60 \\
6.0 & 3.49 & 3.52 & 3.30 & 3.54 \\
6.1 & 3.52 & 3.56 & 3.47 & 3.71 \\
6.2 & 3.71 & 3.92 & 3.65 & 2.88 \\
6.3 & 3.71 & 3.62 & 3.53 & 3.48 \\
6.4 & 3.78 & 3.06 & 3.52 & 3.95 \\
\hline
\end{tabular}


廣瀬 高史・宮内 肇・ 三澤 哲也

表 8: $\alpha_{E}$ と $\bar{S}_{F}$ を変えた場合の $\hat{v}$ 值の差 $\left(\bar{S}_{E}=9.5, \alpha_{F}=20, \sigma_{E}=3.3, \sigma_{F}=1.0\right)$

\begin{tabular}{c|cccc}
\hline $\bar{S}_{F}$ & $\alpha_{E}=120$ & $\alpha_{E}=130$ & $\alpha_{E}=140$ & $\alpha_{E}=150$ \\
\hline 5.7 & 3.35 & 3.36 & 3.51 & 3.61 \\
5.8 & 3.53 & 3.15 & 3.55 & 3.22 \\
5.9 & 3.99 & 3.69 & 3.43 & 3.58 \\
6.0 & 3.59 & 3.58 & 3.44 & 3.62 \\
6.1 & 3.71 & 3.75 & 3.61 & 3.77 \\
6.2 & 3.70 & 3.92 & 3.68 & 3.08 \\
6.3 & 3.86 & 3.77 & 3.55 & 3.57 \\
6.4 & 3.86 & 3.24 & 3.51 & 3.92 \\
\hline
\end{tabular}

表 9: $\bar{S}_{E}$ と $\alpha_{F}$ を変えた場合の $\hat{v}$ 值の差 $\left(\alpha_{E}=110, \bar{S}_{F}=6.0, \sigma_{E}=3.3, \sigma_{F}=1.0\right)$

\begin{tabular}{c|ccccc}
\hline$\alpha_{F}$ & $\bar{S}_{E}=9.0$ & $\bar{S}_{E}=9.1$ & $\bar{S}_{E}=9.2$ & $\bar{S}_{E}=9.3$ & $\bar{S}_{E}=9.4$ \\
\hline 5 & 2.52 & 3.72 & 3.66 & 2.64 & 2.78 \\
10 & 3.00 & 3.25 & 4.22 & 3.30 & 3.32 \\
15 & 3.74 & 3.49 & 3.46 & 3.62 & 4.14 \\
20 & 3.26 & - & - & - & - \\
25 & 3.29 & 3.42 & 3.36 & 3.58 & 3.45 \\
30 & 3.34 & 3.28 & 3.03 & 3.66 & 3.40 \\
\hline
\end{tabular}

表 10: $\bar{S}_{E}$ と $\alpha_{F}$ を変えた場合の $\hat{v}$ 値の差 $\left(\alpha_{E}=110, \bar{S}_{F}=6.0, \sigma_{E}=3.3, \sigma_{F}=1.0\right)$

\begin{tabular}{c|ccccc}
\hline$\alpha_{F}$ & $\bar{S}_{E}=9.5$ & $\bar{S}_{E}=9.6$ & $\bar{S}_{E}=9.7$ & $\bar{S}_{E}=9.8$ & $\bar{S}_{E}=9.9$ \\
\hline 5 & 2.80 & 4.02 & 4.17 & 3.37 & 4.29 \\
10 & 3.32 & 3.93 & 3.62 & 3.74 & 3.97 \\
15 & 4.09 & 4.01 & 3.89 & 3.73 & 3.79 \\
25 & 3.56 & 3.33 & 4.05 & 3.48 & 3.75 \\
30 & 3.56 & 3.29 & 3.83 & 3.62 & 3.81 \\
\hline
\end{tabular}


表 11: $\alpha_{E}$ と $\alpha_{F}$ を変えた場合の $\hat{v}$ 值の差 $\left(\bar{S}_{E}=9.5, \bar{S}_{F}=6.0, \sigma_{E}=3.3, \sigma_{F}=1.0\right)$

\begin{tabular}{c|cccc}
\hline$\alpha_{F}$ & $\alpha_{E}=70$ & $\alpha_{E}=80$ & $\alpha_{E}=90$ & $\alpha_{E}=100$ \\
\hline 5 & 4.11 & 3.90 & 2.71 & 2.81 \\
10 & 3.21 & 4.52 & 3.41 & 3.36 \\
15 & 3.70 & 3.61 & 3.67 & 4.24 \\
25 & 3.62 & 3.35 & 3.68 & 3.48 \\
30 & 3.31 & 3.14 & 3.81 & 3.44 \\
\hline
\end{tabular}

表 12: $\alpha_{E}$ と $\alpha_{F}$ を変えた場合の $\hat{v}$ 值の差 $\left(\bar{S}_{E}=9.5, \bar{S}_{F}=6.0, \sigma_{E}=3.3, \sigma_{F}=1.0\right)$

\begin{tabular}{c|cccc}
\hline$\alpha_{F}$ & $\alpha_{E}=120$ & $\alpha_{E}=130$ & $\alpha_{E}=140$ & $\alpha_{E}=150$ \\
\hline 5 & 3.99 & 3.87 & 2.84 & 2.91 \\
10 & 3.53 & 4.44 & 3.44 & 3.46 \\
15 & 3.77 & 3.68 & 3.83 & 4.15 \\
25 & 3.69 & 3.63 & 3.75 & 3.59 \\
30 & 3.55 & 3.25 & 3.78 & 3.54 \\
\hline
\end{tabular}

表 13: $\sigma_{E}$ と $\sigma_{F}$ を変えた場合の $\hat{v}$ 值の差 $\left(\bar{S}_{E}=9.5, \bar{S}_{F}=6.0, \alpha_{E}=100, \alpha_{F}=20\right)$

\begin{tabular}{c|ccccc}
\hline$\sigma_{F}$ & $\sigma_{E}=3.0$ & $\sigma_{E}=3.2$ & $\sigma_{E}=3.3$ & $\sigma_{E}=3.4$ & $\sigma_{E}=3.6$ \\
\hline 0.5 & 3.59 & 3.36 & 3.59 & 3.72 & 3.69 \\
1.0 & 3.36 & 3.90 & - & 3.49 & 3.54 \\
1.5 & 3.86 & 4.46 & 3.18 & 3.64 & 3.83 \\
2.0 & 4.16 & 3.58 & 3.91 & 3.36 & 3.28 \\
\hline \multicolumn{1}{r}{} \\
\hline
\end{tabular}




\section{参考文献}

[1] Hirata, N., Miyauchi, H. and Misawa, T. (2010). Composition of probit model of simplified UNPV method. Proceedings of 16th ICEE, PM-01.

[2] Misawa, T. (2010). Simplification of utility indifference net present value method. Oikonomika, 46, 123-135.

[3] Miyauchi, H., Miyahara K., Misawa T. and Okada, K. (2007). Risk assessment for generation investment based on utility indifference pricing, Proceedings of CIGRE Osaka Symposium, 405.

[4] 木島正明, 中岡英隆, 芝田隆志 (2008).「リアルオプションと投資戦略」. 朝倉書店.

[5] 平田直樹, 宮内肇, 三澤哲也 (2010). “UNPV 法の簡約化によるプロビットモデルの構成と 検証”。「電気学会電力技術・電力系統技術合同研究会資料」, PE-10-071/PSE-10-070.

[6] 宮原孝夫 (2006). “期待効用理論に基づくプロジェクトの価值評価法”. Discussion Papers in Economics, Nagoya City University, 466.

[7] 三輪昌隆, 宮原孝夫 (2010). “設備維持管理計画の価值評価に対する制御マルコフ過程によ るリアルオプションアプローチ”。「リアルオプション研究」, 3, 185-204. 